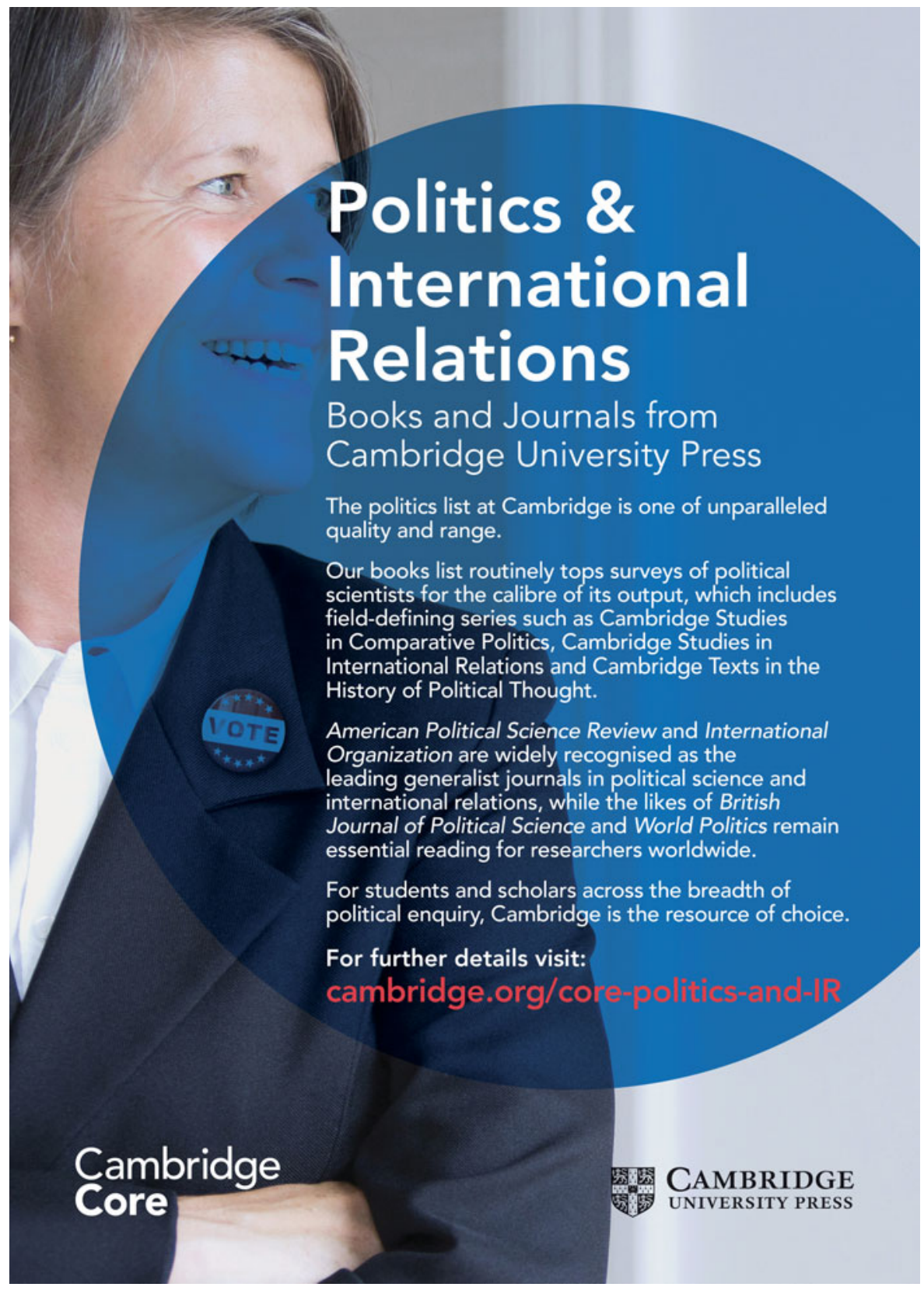



POSTAL SERVICE (All Periodicals Publications Except Requester Publications)

\begin{tabular}{|c|c|c|}
\hline \multirow{2}{*}{$\begin{array}{l}\text { 1. Publication Title } \\
\text { The Review of Politics }\end{array}$} & 2. Publication Number & \multirow{2}{*}{$\begin{array}{l}\text { 3. Filing Date } \\
10 / 1 / 2021\end{array}$} \\
\hline & $463-780$ & \\
\hline 4. Issue Frequency & 5. Number of Issues Published Annually & 6. Annual Subscription Price \\
\hline Quarterly Winter, Spring, Summer, Fall & 4 & $\$ 229.00$ \\
\hline \multicolumn{2}{|c|}{ 7. Complete Maling Address of Known Office of Publication (Not printer) (Street, city, county, state, and ZIP+48) } & $\begin{array}{l}\text { Contact Person } \\
\text { Nina lammatteo }\end{array}$ \\
\hline 1 Liberty Plaza & & $\begin{array}{l}\text { Telephone (Include area code) } \\
212-337-5004\end{array}$ \\
\hline \multicolumn{3}{|c|}{ 8. Complete Maling Address of Headquarters or General Business Office of Publisher (Not printer) } \\
\hline \multicolumn{3}{|c|}{$\begin{array}{l}\text { Cambridge University Press } \\
\text { Edinburgh Building, Cambridge CB2 2RU, England }\end{array}$} \\
\hline \multicolumn{3}{|c|}{ 9. Full Names and Complete Mailing Addresses of Publisher, Editor, and Managing Editor (Do not leave blank) } \\
\hline $\begin{array}{l}\text { Publisher (Name and complete maaling address) } \\
\text { Cambridge University Press } \\
1 \text { Liberty Plaza } \\
\text { New York. NY } 10006\end{array}$ & & \\
\hline
\end{tabular}

Editor (Name and complete mailing address)

Ruth Abbey, University of Notre Dame, Political Science, 217 O'Shaugnessy Hall, Notre Dame, Indiana,United States,46556

Managing Editor (Name and complete mailing address)

10. Owner (Do not leave blank. If the publication is owned by a corporation, give the name and address of the corporation immediately followed by the names and addresses of all stockholders owning or holding 1 percent or more of the total amount of stock. If not owned by a corporation, give the names and addresses of the individual owners. If owned by a partnership or other unincorporated firm, give its name and address as well as those of each individual owner. If the publication is published by a nonprofit organization, give its name and address.)

Complete Mailing Address

\begin{tabular}{l|l}
\hline Full Name & Complete Mailing Address \\
\hline University of Notre Dame & University of Notre Dame
\end{tabular}

\begin{tabular}{l|l}
\hline & Notre Dame, IN 46556 \\
\hline & \\
\hline & \\
\hline & \\
\hline
\end{tabular}

11. Known Bondholders, Mortgagees, and Other Security Holders Owning or Holding 1 Percent or More of Total Amount of Bonds, Mortgages, or Other Securities. If none, check box $\longrightarrow \mathbf{X}$ None

\begin{tabular}{l|l}
\hline Full Name & Complete Mailing Address \\
\hline & \\
\hline & \\
\hline & \\
\hline & \\
\hline 12. Tax Status (For completion by nonprofit organizations authorized to mail at nonprofit rates) (Check one) \\
The purpose, function, and nonprofit status of this organization and the exempt status for federal income tax purposes: \\
$\square$ Has Not Changed During Preceding 12 Months \\
$\square$ Has Changed During Preceding 12 Months (Publisher must submit explanation of change with this statement)
\end{tabular}

PS Form 3526, July 2014 [Page 1 of 4 (see instructions page 4)] PSN: 7530-01-000-9931 PRIVACY NOTICE: See our privacy policy on www. usps.com. 


\begin{tabular}{|c|c|c|c|c|}
\hline \multicolumn{3}{|c|}{$\begin{array}{l}\text { 13. Publication Title } \\
\text { The Review of Politics }\end{array}$} & \multicolumn{2}{|c|}{$\begin{array}{l}\text { 14. Issue Date for Circulation Data Below } \\
\text { AUGUST } 2021\end{array}$} \\
\hline \multicolumn{3}{|c|}{ 15. Extent and Nature of Circulation } & $\begin{array}{l}\text { Average No. Copies } \\
\text { Each Issue During } \\
\text { Preceding } 12 \text { Months }\end{array}$ & $\begin{array}{l}\text { No. Copies of Single } \\
\text { Issue Published } \\
\text { Nearest to Filing Date }\end{array}$ \\
\hline \multicolumn{3}{|c|}{ a. Total Number of Copies (Net press run) } & 244 & 235 \\
\hline \multirow{4}{*}{$\begin{array}{l}\text { b. Paid } \\
\text { Circulation } \\
\text { (By Mail } \\
\text { and } \\
\text { Outside } \\
\text { the Mail) }\end{array}$} & (1) & $\begin{array}{l}\text { Mailed Outside-County Paid Subscriptions Stated on PS Form } 3541 \text { (Include paid } \\
\text { distribution above nominal rate, advertiser's proof copies, and exchange copies) }\end{array}$ & 113 & 106 \\
\hline & (2) & $\begin{array}{l}\text { Mailed In-County Paid Subscriptions Stated on PS Form } 3541 \text { (Inctude paid } \\
\text { distribution above nominal rate, advertiser's proof copies, and exchange copies) }\end{array}$ & 0 & 0 \\
\hline & (3) & $\begin{array}{l}\text { Paid Distribution Outside the Mails Including Sales Through Dealers and Carriers, } \\
\text { Street Vendors, Counter Sales, and Other Paid Distribution Outside USPS }\end{array}$ & 72 & 76 \\
\hline & (4) & $\begin{array}{l}\text { Paid Distribution by Other Classes of Mail Through the USPS } \\
\text { (e.g. First-Class Mail's) }\end{array}$ & 0 & 0 \\
\hline \multicolumn{3}{|c|}{ c. Total Paid Distribution [Sum of 15b (1), (2), (3), and (4)] } & 185 & 182 \\
\hline \multirow{4}{*}{$\begin{array}{l}\text { d. Free or } \\
\text { Nominal } \\
\text { Rate } \\
\text { Distribution } \\
\text { (By Mail } \\
\text { and } \\
\text { Outside } \\
\text { the Mail) }\end{array}$} & (1) & Free or Nominal Rate Outside-County Copies included on PS Form 3541 & 0 & 0 \\
\hline & (2) & Free or Nominal Rate In-County Copies Included on PS Form 3541 & 0 & 0 \\
\hline & (3) & $\begin{array}{l}\text { Free or Nominal Rate Copies Mailed at Other Classes Through the USPS } \\
\text { (e.g. First-Class Mail) }\end{array}$ & 0 & 0 \\
\hline & (4) & Free or Nominal Rate Distribution Outside the Mall (Carriers or other means) & 0 & 0 \\
\hline \multicolumn{3}{|c|}{ e. Total Free or Nominal Rate Distribution (Sum of 15d (1), (2), (3) and (4)) } & 0 & 0 \\
\hline \multicolumn{3}{|c|}{ f. Total Distribution (Sum of $15 \mathrm{c}$ and $15 \mathrm{e}$ ) } & 185 & 182 \\
\hline \multicolumn{3}{|c|}{ 9. Copies not Distributed (See Instructions to Publishers \#4 (page \#3)) } & 59 & 53 \\
\hline \multicolumn{3}{|c|}{ h. Total (Sum of $15 /$ and g) } & 244 & 235 \\
\hline \multicolumn{3}{|c|}{$\begin{array}{l}\text { i. Percent Paid } \\
\text { (15c divided by } 15 f \text { times } 100)\end{array}$} & $100 \%$ & $100 \%$ \\
\hline
\end{tabular}

- If you are claiming electronic copies, go to line 16 on page 3. If you are not claiming electronic copies, skip to line 17 on page 3 . 
Statement of Ownership, Management, and Circulation POSTAL SERVICE $\odot$ (All Periodicals Publications Except Requester Publications)

\begin{tabular}{l|l|l}
\hline 16. Electronic Copy Circulation & $\begin{array}{l}\text { Average No. Copies } \\
\text { Each Issue During } \\
\text { Preceding 12 Months }\end{array}$ & $\begin{array}{l}\text { No. Copies of Single } \\
\text { Issue Published } \\
\text { Nearest to Filing Date }\end{array}$ \\
\hline a. Paid Electronic Copies & & \\
\hline b. Total Paid Print Copies (Line 15c) + Paid Electronic Copies (Line 16a) & & \\
\hline c. Total Print Distribution (Line 15f) + Paid Electronic Copies (Line 16a) & & \\
\hline d. Percent Paid (Both Print \& Electronic Copies) (16b divided by 16c $\times 100)$ & & \\
\hline
\end{tabular}

X I certify that $50 \%$ of all my distributed copies (electronic and print) are paid above a nominal price.

\section{Publication of Statement of Ownership}

$X$ If the publication is a general publication, publication of this statement is required. Will be printed

$\square$ Publication not required.

in the winter issue of this publication.

18. Signature and Title of Editor, Publisher, Business Manager, or Owner

Nina lammatteo

$10 / 1 / 2021$

I certify that all information furnished on this form is true and complete. I understand that anyone who furnishes false or misleading information on this form or who omits material or information requested on the form may be subject to criminal sanctions (including fines and imprisonment) and/or civil sanctions (including civil penalties) 


\section{The Review of Politics INSTRUCTIONS TO CONTRIBUTORS}

\begin{abstract}
AIMS AND SCOPE. The Review of Politics publishes primarily philosophical and historical studies of politics, especially those concentrating on political theory and American political thought. The journal also includes thoughtful scholarly reflections on all aspects of politics-including analysis of institutions and techniques, international relations, comparative politics, literary reflections on politics or political interpretations of literary works, constitutional theory and practices.
\end{abstract}

\section{MANUSCRIPT SUBMISSION AND}

REVIEW. To submit a manuscript for consideration please send an electronic file (formatted in MS Word):

\section{THE REVIEW OF POLITICS ONLINE SUBMISSION}

http://mc.manuscriptcentral.com/cup/rop

Complete instructions are provided on the website. The menu will prompt the author to provide all necessary information, including the manuscript category, contact information for the corresponding author (phone number, fax number, email address), and suggested reviewers. The website will automatically acknowledge receipt of the manuscript and provide a reference number. The Editor will assign the manuscript to anonymous reviewers and every effort will be made to provide the author with a review in a timely fashion.

Authors uncomfortable with online submission may send their manuscript as an email attachment to rop.editor.1@nd.edu:

Editor, The Review of Politics

University of Notre Dame

2005 Jenkins Nonovic Halls

Notre Dame, IN 46556-7000

574-631-6623

ROP.Editor.1@nd.edu

reviewofpolitics.nd.edu

BOOK REVIEWS. All correspondence regarding book reviews should be sent to our editorial offices at Rop.Editor.1@nd.edu.

MANUSCRIPT LENGTH. Normal length of published manuscripts is $8,000-11,000$ words. The entire manuscript, including notes and quotations, should be double-spaced.
Author anonymity. Because manuscripts are evaluated anonymously they should not bear the author's name or institutional affiliation. Please remove all references or acknowledgments that might indicate the identity of the author.

Abstract and keywords. All article submissions should include an abstract of 100-150 words.

\section{MANUSCRIPT PREPARATION AND \\ STYLE. The Review of Politics follows the Chicago Manual of Style for standards of citation, punctuation, and other editorial considerations.}

Figures and tables. Appendices, tables, and figures should be numbered consecutively throughout the article and be included on separate pages appearing after the reference section. Each figure must be submitted electronically as a separate file. Electronic versions should submitted as $1200 \mathrm{dpi}$ TIFF or EPS files at $100 \%$ of a suitable final size. Charts, graphs, or other artwork should be professionally rendered and computer generated.

\section{COPYEDITING AND PAGE PROOFS.}

The publisher reserves the right to copyedit and proofread all articles accepted for publication. Page proofs of an article will be sent to the lead author of an article for correction of typographical errors only; authors must notify the publisher or the editorial office of any changes within 72 hours of receipt of proof or approval will be assumed.

\section{COPYRIGHT TRANSFER AGREEMENT.} Papers with multiple authors are reviewed with the assumption that all authors concur with its submission. A Copyright Transfer Agreement, with certain specified rights reserved by the author, must be signed and returned to the Editor by senior authors of accepted manuscripts, prior to publication. The Review of Politics does not accept manuscripts for review that are under review elsewhere, previously published, or already committed for publication. 
BOOKS REVIEWED

Kathryn Sikkink, The Hidden Face of Rights: Toward a Politics of Responsibilities

Hélène Landemore, Open Democracy: Reinventing Popular Rule for the Twenty-First Century

David Estlund, Utopophobia: On the Limits (If Any) of Political

$$
\text { Philosophy }
$$

Edward Hall, Value, Conflict, and Order: Berlin, Hampshire, Williams, and the Realist Revival in Political Theory

Elizabeth Frazer and Kimberly Hutchings, Violence and

$$
\text { Political Theory }
$$

... and more

FORTHCOMING IN THE NEXT ISSUE

Chris Campbell, "The Rhetoric of Hobbes"s Translation of Thucydides"

Mark Fisher, "Thucydides's Tragic Science of Democratic Defeat"

Yoav Fromer, "Daniel Patrick Moynihan and the Politics of Tragedy"

Joshua Simon, "Overcoming the other America: José Martís Immanent Critique of the Unionist Paradigm"

A Symposium on Ines Valdez's Transnational Cosmopolitanism: Kant, Du Bois, and Justice as a Political Craft. Contributors include Charles Mills, Emma McKinnon, and Thomas Donahue, with a response by Inez Valdez

\section{Cambridge Core}

For further information about this journal please go to the journal website at: cambridge.org/rop 